\title{
Regulações Institucionais e Integração \\ Cultural: um Binômio Viável
}

Eliane Ganev*

Resumo: 0 artigo a seguir explora e enfatiza alguns aspectos da pesquisa de doutorado da autora. Apresenta as formas eprincípios organizativos de grupos de Alcoólicos Anônimos no Brasil eno Uruguai, e analisa relações entre suas regulações institucionais e 0 potencial de integração cultural da associação - concebida, para os propósitos da pesquisa e do presente texto, como um movimento cultural ${ }^{1}$.

Palavras-chave: Regulações Institucionais, Integração Cultural, Sub-regulação, Auto-regulação, Dicotomias, Alcoólicos Anônimos, Culturas Locais, Cultura Institucional.

Abstract: This article proposes to explore and emphasize some aspects of the author's doctorate thesis. It presents some forms, and organizational principles of the Alcoholic's Anonymous or (AA) in Brazil and Uruguai, as well as analyses relationship between the group's institutional regulations and the institution's potential for cultural integration. Thus, this institution can be concieved to be, for the aim of the thesis and the article, as a cultural movement ${ }^{1}$.

Keywords: Regulações Institucionais, Integração Cultural, Sub-regulação, Auto-regulação, Dicotomias, Alcoólicos Anônimos, Culturas Locais, Cultura Institucional.

\section{Introdução}

Alcoólicos Anônimos (AA) surgiu nos anos 30 do século XX, nos Estados U nidos, como uma proposta leiga de superação do alcoolismo voltada para homens e mulheres cuja forma de beber tivesse se tornado, a seus próprios olhos, um problema. N os seus quase setenta anos de existência e de crescimento (lento mas constan-

* Doutora em Integração da América Latina pelo Programa de Pós-Graduação em Integração da América Latina - PROLAM/USP. E-mail: elianeganev@ terra.com.br.

${ }^{1}$ Dessemodo, osaprofundamentos conceituaisdasnoọoes aqui trabalhadas, a íntegra dos enunciadosedos dados collidos no trabalho de campo, bem como a bibliografia completa da pesquisa, encontram-seno corpo da tese (Ganev 2002).

In this form, the concepts and notions which are explored here, the totality of the hypothesis and the data collected during fieldwork, as well as the complete bibliography can be found in the doctorate thesis (Ganev 2002). 
te), ramificou-se para pouco mais de 140 países e noventa mil grupos, congregando atualmente cerca de dois milhões de membros, segundo seus próprios números, sempre figurando entre as alternativas com índices significativos de sucesso na recuperação a longo prazo dealcoólicose ostentando, tanto em extensão geográfica como internamente a cada um de seus grupos, uma diversidade cultural instigante.

Vaillant (1999: 213) menciona sua expansão "na miserável comunidade hindu, na Índia, na anglofóbica tomadora de vinho, a França, na Espanha católica e no Japão budista", al ém da Rússia, Arábia Saudita, Brasil, H ong Kong, Zimbabweeoutros- aos quais pode-se acrescentar os países da América Latina, abrindo um considerável leque de diferenças entre si e também em contraponto à própria cultura de $A A$, fortemente ligada à versão norte-americana do protestantismo ocidental. E essa diversidadecultural atestada pela abrangência geográfica da associação manifesta-se também internamente, no micro-cosmo e na cotidianidade dos grupos de AA. A título de exemplo, nos grupos (do Brasil e do U ruguai) que foram incluídos no trabalho de campo da pesquisa é regra geral a convivência profunda e solidária entre ricos e pobres, jovens, adultos e anciãos, titulados em universidades e analfabetos, homens e mulheres de todas profissões e preferências sexuais, gente "de direita" e "deesquerda", ateusecrentes filiados às mais diversas religiões, sincretismos e dissidências que proliferam em nosso continente, além, éclaro, da presença detodas as etnias emestiçagenstambém existentes entre latinoamericanos em geral, brasileiros e uruguaios em particular.

Tal característica chamou a atenção da pesquisadora sobre a experiência coletiva $\operatorname{dos} A A s$, que muito tem sido investigada do ponto de vista estritamente médico, mas tem passado praticamente despercebida enquanto movimento cultural dotado de características singulares. Como estudiosa do campo da comunicação social e, especificamente, das relações entre comunicação, cultura e produção de subjetividade, voltei o foco da pesquisa para esses aspectos ainda in explorados da existência e do funcionamento de Alcoólicos Anônimos, um dos quais aprofundou a compreen são em torno das relações entre suas formas organizativo-regulatórias ea integração cultural acima citada, tema que constitui a base do presente artigo.

D esse modo, proponho aqui um certo percurso do pensamento, configurado como estrutura e seqüência do texto: primeiramente, que olhemos o próprio alcoolismo como um fenômeno cultural, ou em outras palavras, queampliemoso olhar comumente reducionista- que o concebe ora como questão "moral", ora como problema de saúde pública cujo enfrentamento seria atribuição específica desse campo de conhecimento e de formulação de políticas espeć́ficas - , visitando seus significados remotos e recentes no imaginário coletivo; em seguida, que visualizemos uma síntese da proposta de Alcoólicos Anônimos paralidar com o alcoolismo de seus membros; finalmente, veremoso 
desenho institucional eas regulações queAA construiu para viabilizar a prática permanente de sua proposta, no contexto dos quais a integração cultural poderá ser compreendida como um benéfico (e coerente) "efeito colateral".

\section{Alcoolismo é cultura? ${ }^{2}$}

Falar deal coolismo épisar em terreno minado, a começar pela tentativa de resgatálo historicamente, uma vez que a própria descoberta do processo de fermentação alcoólica não tem origem definida. A arqueologia trabalha com a hipótese de que povos antigos, convivendo com vinhedos selvagens, possam ter tido suas primeiras experiências etílicas. Sementes de uva cultivadas e armazenadas, encontradas em sítios arqueológicos datados de até 8.000 anos a.C., permitem supor o fabrico de al gum tipo de vinho. As citações bíblicas sobre videiras e embriaguez aparecem já no Velho Testamento. Reis, sacerdotes, curas, feiticeiros, guerreiros, produtores, comerciantes e outras personagens medievais que cultivaram hábitos ligados ao uso de diferentes beberagens pontuam a história, a arqueologia, a antropologia e a mitologia de todos os continentes. N o século XX, o filósofo e psicólogo W illiam James (1995) estudou a vida de homens e mulheres que vieram a tornar-se religiosos católicos e protestantes, muitos dos quais foram beberrões inveterados antes de experimentarem al gum tipo de "conversão". N a América, algumas culturas pré-colombianas já produziam bebidas fermentadas (C ardoso 1986). No Brasil, a cachaça, originalmente um sub-produto da fabricação do açúcar, foi consumida por animais e escravos muito antes de vir a tornar-se bebida nacional ${ }^{3}$. Com tais breves menções, quero apenas enfatizar a quantidade e a pluralidade dos legados culturais com os quais lidamos necessariamente ao enfrentar hoje a questão do al coolismo.

Além disso, a emergência das sociedades industriais, trazendo consigo as formas sócio-políticas e os sempre drásticos movimentos da acumulação capitalista ${ }^{4}$, operou como um divisor de águas em todos os campos da aventura humana e, no que se

\footnotetext{
${ }^{2}$ No capítulo I da tese de doutorado da autora (Ganev 2002) encontra-se uma versão mais detalhada da discussão desse tópico, enos seus Anexos está a íntegra dos estudos de campo que lhe serviram de base.

${ }^{3}$ E, do mesmo modo, práticas de abstinência alcoólica têm acompanhado, quase que pari passu, as práticas etílicas de todos os tempos e lugares, fazendo-lhes contraponto nos mais díspares contextos, e com significados igualmente múltiplos: como forma de diferenciação hierárquica para definir status social ou religioso, sinal ou prova de pureza espiritual (mastambém de puritanismo num sentido pejorativo), prescrição médica, busca da saúde perfeita etc.

${ }^{4}$ Colonialismo, escravismo, diáspora e destruição de povos nativos de todas as regiões terrestres, expulsão das populações rurais, formação das urbes e das grandes aglomerações fabris, imperialismo, guerras, revoluções de
} 
refere ao assunto em questão, temos que produtos, práticas e usos culturais etílicos até então enraizados e dotados de sentido foram sendo absorvidos por esses macroprocessos e convertidos em mercadorias, fontes de acumulação privada e de arrecadação tributária pelo poder público, objetos de desejo e de consumo. É no reverso dessa moeda que encontramos a generalização do al coolismo como patologia endê mica, questão social, problema de saúde pública, objeto de pesquisas científicas e alvo de (escassas) políticas públicas.

0 novo contexto não eliminou, contudo, aqueles influxos ancestrais no imaginário das populações que agora convivem com o alcoolismo em seu cotidiano, de modo que cada reencenação desse drama contemporâneo mobiliza e faz emergir, na consciência individual e coletiva, um repertório imenso, fragmentário e incoerente designificados e de afetos sempre viscerais, que acrescentam complexidade ao problema. Podemos visualizar tal repertório "ouvindo" vozes oriundas de algumas esferas da vida social contemporânea: o conhecimento, a arte, o jornalismo, a publicidadee 0 assim chamado senso comum.

N o campo do conhecimento, em particular nas ciênciasmédicas, polêmicasfundamentais e pontuais dividem historicamente a comunidade científica em torno de muitos aspectos ligados ao beber descontrolado e, ao serem social mente compartilhadas, estendem a divisão também ao mundo político, religioso, social e familiar: 0 alcoolismo é um problema moral, uma doença ou um sintoma? É progressivo ou não? Curável ou não? H ereditário ou não? Primário ou não? Q uais os critérios para o diagnóstico? Q ual a sua etiologia? E o tratamento mais eficaz? U m al coólico pode voltar a beber controladamente? AA é útil na recuperação do al coolismo?

0 modo como tais questões vêm sendo respondidas e, mais que isso, o modo como as respostas da ciência chegam (ou não) às pessoas, influencia diretamente 0 comportamento cotidiano de policiais, jornalistas, juízes, professores, pesquisadores, empresários e demais atores sociais que, de al gum modo, são confrontados com o problema, assim como a criação (ou não) de políticas públicas, instituições eserviços para fazer frente às demandas, além, é claro, de afetar direta ou indiretamente a vida dos al coólicos. E o fato de as respostas serem quase sempre contraditórias e de natureza não conclusiva gera, dentreoutros desdobramentos: omissõesou disparidades

perspectiva socialista, movimentos de libertação nacional, totalitarismos e ditaduras, a posterior desestruturação e reestruturação geo-política fundada na globalização neoliberal, a destruição dos parques industriais das regiões economicamente submetidas, desemprego e subemprego crônicos...

${ }^{5}$ Perguntas como essas serviram como pontos de partida ao trabalho de Vaillant (1999). 
normativas e legais, prescrições médicas desencontradas, diagnósticos equivocados, tratamentos inadequados, confusão, morte, enfim, perdas de todo tipo e tamanho.

Além disso, se como regra geral o modelo médico reduz 0 alcoolismo a bem menos do que ele é, por outro lado, a ignorância generalizada a respeito deste seu aspecto, socialmente preponderante desde que se tornou problema de saúde pública, chega a ser mais danosa do que sua redução. Ainda hoje os programas das escolas de medicina, psicologia, serviço social, direito e outras áreas vinculadas omitem ou relegam o tema a um grau de insignificância desproporcional em relação à realidade social, e é grande a quantidade de profissionais de saúde, tanto quanto de outros atores sociais e de alcoólicos que simplesmente desconhecem a dimensão patológica e endêmica do fenômeno.

Enquanto isso, a arte trata de buscar e oferecer outras visões, com sua peculiar capacidade de encontrar e expressar verdades profundas subjacentes aos acontecimentos. Assim, por exemplo, o beber problemático é um dos temas caros às letras de canções populares de diversos gêneros e idiomas. A título de exemplo, "ouçamos" a seguir a descrição completamente cai pira - conforme Ribeiro (1995) e C ândido (2001) - e despudorada (isenta de moralismos), em primeira pessoa do singular, de um caso gravíssi mo dealcoolismo feminino, cantada por I nezita Barroso há décadas por expressar, de maneira muito leve, verdades em geral constrangedoras. Em "M oda da Pinga" aparece o riso popular no sentido bakthiniano, ou seja, do riso que "expressa uma opinião sobre um mundo em plena evolução no qual estão incluídos os que riem", ao contrário do humor negativo, cujo autor "coloca-se fora do objeto aludido e opõe-se a ele", destruindo com isso "a integridade do aspecto cômico do mundo" (Bakthin 1993):

Moda da pinga

( 0 chelsis Laureano e Raul Torres, interpretação de Inezita Barroso)

Co'a marvada pinga é que eu me atrapaio/ Eu entro na venda e já dô meus taio Pego no copo e dali num saio/ Ali mesmo eu bebo, ali mesmo eu caio Só pra carregá é que eu dô trabaio, oi lá!

Venho da cidade, já venho cantando/ Trago um garrafão que venho chupando Venho pros caminho, venho trupicando/ Chifrando osbarranco, venho cambeteando E no lugar que eu caio já fico roncando, oi lá!

0 marido me disse, ele me falô/ Largue de bebê, peço pro favor

Prosa de home nunca dei valor/ Bebo com o sor quente pra esfriá o calô

E bebo de noite que é pra fazer suadô, oi lá!

Cada vez que eu caio, caio deferentel M e arço pra trás e caio pra frente Caio devagar, caio derepente/ Vou de currupio, vou deretamente $M$ as sendo de pinga eu caio contente, oi lá! 
Pego o garrafão e já balanceio/ Q ue é pra mor de vê se tá mesmo cheio $\mathrm{N}$ um bebo de vez por que acho feio/ $\mathrm{N}$ o primeiro gorpe chego inté no meio No segundo trago é que eu desvazeio, oi lá!

Eu bebo da pinga porque gosto dela/ Eu bebo da branca, bebo da amarela

Bebo no copo, bebo na tigela/ Bebo temperada com cravo e canela

Seja quarqué tempo vai pinga na goela, oi lá!

Eu fui numa festa no rio Tietêl Eu lá fui chegando no amanhecê Já me deram pinga pra mim bebêl tava sem fervê

Eu bebi demais e fiquei mamada/ Eu caí no chão e fiquei deitada

Aí eu fui pra casa de braços dado/ Ai de braço dado ai com dois sordado

Ai, muito obrigado!

No extremo oposto, o trágico, a Bossa N ova é também pródiga no tema - é notório que vários de seus autores bebiam excessivamente e adensaram o imaginário coletivo ao compor e interpretar, com o conhecimento de quem bebe, os modos de ver e os padecimentos de quem convive com os que bebem, além de popularizar e legitimar as racionalizações que classicamente os bebedores empregam a fim dejustificar seus excessos (dores de amores, traições, ingratidão, solidão, incompreensão, proteção excessiva, depressão, ódio, inimizades ):

Com açúcar, com afeto

(Chico Buarque de Holanda)

Com açúcar, com afeto/ fiz seu doce predileto/ pra você parar em casa/ Q ual o quê!/ Com seu terno mais bonito/ você sai, não acredito/ quando diz que não se atrasa Vocêdiz queéoperário/ vai em busca de um salário/ pra poder mesustentar/ Q ual o quêl/ N o caminho da oficina/ há um bar em cada esquina/ pra você comemorar /Sè láo quel/ Se quealguém vai chegar junto/ vocêvai puxar assunto/ discutindo futebol e ficar olhando as saias/ de quem vive pelas praias/ coloridas pelo sol.

Vem a noite, mais um copo/ sei que, al egro ma non troppo/ você vai querer cantar na caixinha, um novo amigo/ vai bater um samba antigo/ pra você rememorar... Q uando a noite, enfim, Ihe cansa/ você vem feito criança/ a chorar o meu perdão Q ual o quêl/ D iz pra eu não ficar sentida/ diz que vai mudar de vida/ pra agradar meu coração

\footnotetext{
${ }^{6}$ Note-se que esses eventos amiúde fazem parte da vida dos bêbados, porém, quase sempre como consequiências do alcoolismo e não como causas. A pesquisa de Vaillant (1999), bem como sua revisão da literatura médica a respeito, é eloqüente quanto a esse ponto.
} 
E ao lhe ver assim cansado/ maltrapilho e maltratado/ ainda quis me aborrecer Q ual o quê!/ Logo vou esquentar seu prato/ dou um beijo em seu retrato e abro os meus braços pra vocêl Com açúcar, com afeto.

D e modo geral, as canções populares oferecem ao imaginário coletivo um elemento detotalidade ligado ao alcoolismo: elas contam, ainda que demodo involuntário, fragmentário e distorcido, que o beber descontrolado associa-se a uma visão de mundo, uma racionalidadee uma cultura, a todo um modo de vida centrado na bebida e que inclui, por exemplo: auto-isenção e responsabilização de terceiros pelo que acontece ao bebedor, vitimização, minimização, violência, depressão, negação, irresponsabilidade, indiferença, egocentrismo crescente etc. É certo queas letras a um só tempo nos confrontam com visões idealizadas e glamourosas, ou condenatórias e aviltantes dos bêbados, mas a licença poética opera aí como um aviso permanente da sua dimensão ficcional, a qual étão forte e real quanto sua capacidade de narrar o real profundo.

Q uanto ao jornalismo - que supostamente é espaço e veículo de informações qualificadas - , o que se vê no cotidiano é praticamente o mesmo desconhecimento que permeia a sociedade. É claro que, eventualmente, aparecem artigos e reportagens adequadamente informados e informativos, mas, proporcional mente ao volume de aconteci mentos direta e indiretamente ligados ao al coolismo, são como vagalumes voando à noite: frágeis, ínfimos e nunca se sabe aonde ou quando voltarão a iluminar um pouquinho seu entorno escuro.

0 fato principal, que torna a acontecer a cada dia, é que a imensa massa de material jornalístico produzido para o rádio, tevêaberta ejornais (isto é, para a população em geral), especificamentenas editorias de "polícia", "cidades" e "comunidade" (incluindo trânsito, Justiça, Saúde, Trabal ho, lazer e outras classificações), está substancialmente atravessada por casos de al coolismo: criminal idade e violência (fatais ou não), acidentes de todo tipo, disputas judiciais, estatísticas, problemas de saúde e outras tantas notícias, mas exatamente este fato concreto, mensurável e de tão elevado inte resse humano, é ignorado. A grande maioria dos textos concebe como incidentes primários o que na verdade são conseqüências. Vamos a mais um pequeno exemplo:

Jornalista é espancado até a morte em Belém

BELÉM - 0 repórter policial Josemar Baía, de 37 anos, foi morto a socos e pontapés, anteontem, por dois homens. O s acusados, o investigador Luiz Sérgio Torres e o fabricante de chaves J orge Elias M oraes Rodrigues estavam armadose bebendo em um bar em Icoaraci, em Belém, com a mulher do jornalista, M aria de $N$ azaré Leal. Baía foi tomar satisfações, deu um tapa na mulher, mas acabou espancado até a morte. (Jornal 0 Estado deS. Paulo, 21/5/2000, C-7) 
N esse sentido e paradoxal mente, a tão apregoada objetividade jornalística se torna até realidade, porém, de modo inconsciente e involuntário: como regra geral, o noticiário diário reflete quase à perfeição a ignorância preval ecente na sociedade em torno do problema e só nessa medida é transparente, deixa-se atravessar e permite ver através de sua espessura. Em outras palavras, a praxe é que em nenhum momento se constrói qualquer relação explícita e direta, por hipotética que seja, entre o acontecimento e o modo de beber de alguns dos envolvidos; tal relação pode apenas ser inferida por leitores que tenham alguma familiaridade ou algum acúmulo de informações e reflexão sobre 0 assunto.

E tal omissão pode ser tudo, menos inofensiva, no que se refere a alimentar o imaginário coletivo. A mera referência à bebida alcoólica, em qualquer lugar de um texto queinforma sobre um ato violento, por exemplo, sugere uma violência "gratuita", tão absurda quanto hedionda, que reforça estereótipos classistas/racistas - já que a criminalidade e a violência etílicas das classes proprietárias em geral não chegam às páginas policiais. Jamais se menciona, por exemplo, numa nota sobre um crime cometido num bar de periferia, os efeitos do ál cool sobre o sistema nervoso central, sobre a agressividade e a capacidade de auto-censura. Embora tais informações em nada pudessem justificar condutas violentas, poderiam fortalecer a compreensão de sua eclosão quando derivadas do alcoolismo e, portanto, a construção coletiva e plural de sua prevenção, além de modos alternativos de lidar com elas.

M as tem mais. M esmo nas ocorrências em que a intoxicação alcoólica éevidentee não pode ser ignorada no texto jornalístico - a bebedeira ao volante, por exemplo - , ainda assim o problema poderá não ser devidamente enfocado. 0 alcoolismo possivelmente será indicado como causa de acidentes apenas nos casos em que os motoristas apresentavam "evidências de embriaguez". Jamais se leva em conta o fato de que a abstinência repentina, num alcoólico, é tão (ou mais) capaz de provocar acidentes quanto um episódio de bebedeira, porque produz uma síndrome (a popular ressaca) caracterizada por tremores, sudorese, taquicardia, diarréia, desorientação espacial, desordem motora, terrível mau humor e outros sintomas grandemente comprometedores do desempenho esperado de um motorista (o próprio Código de Trânsito desconhece as "evidências de abstinência"). Também nunca se cogita sobre o fato (cultural) de que o alcoolismo co-produz um modo de vida fundado na imprudência, irresponsabilidade, agressividadee egocentrismo, permitindo queal coólicos (al coolizados ou não) saiam por aí em veículos sem condições de uso.

Contudo, ao deixarmos de lado o jornalismo e passarmos à publicidade, por um passe de mágica entramos num mundo em que beber é signo de sucesso, sensualidade, al egria e da suprema ânsia humana por transcendência (superação de si, vislum- 
bre do sentido da vida). 0 paradoxo dessa concepção publicitária, que norteia via de regra a propaganda comercial desse tipo de mercadoria, é que as peças atingem em cheio a lógica do alcoólico em potencial, ou seja, daqueles 10 a 15\% de crianças, jovens, adultose anciãos de ambos os sexospara osquaisbeber éou virá a ser efetivamente um "assunto" e, no fundo, o centro de suas vidas, a pseudo-solução de seus problemas ea pseudo-realização de seus desejos e utopias. M ais que isso, as propagandas em geral descrevem fidedigna e acriticamente os efeitos do ál cool sobre a percepção dos al coólicos no jargão dos membros de AA, depois de tomar uma, "a vida muda" e o bebum torna-se, para ele mesmo (embora nunca para os outros) o mais bonito, o mais rico e o mais inteligente do lugar.

0 fosso entre as imagens publicitárias e a realidade de milhões de alcoólicos em todo o mundo, tanto como a absoluta coerência entre o poder da indústria de bebidas e a omissão do poder público no que se refere à prevenção do alcoolismo, faz lembrar em plenitude a descrição de M arx (1974) em torno da questão da dual idade da necessi dade humana: esta poderia significar "riqueza de necessidades humanas" e implicar "um novo modo de produção e um novo objeto da mesma" (riqueza), "N ova afirmação da força essencial humana e novo enriquecimento da essência humana". Porém, continua o autor, "D entro da propriedade privada, o significado inverso":

(...) 0 aumento da produção e das necessidades se converte no escravo engenhoso e sempre calculador de apetites inumanos, refinados, anti-naturais e imagi nários. A propriedade privada não sabe fazer da necessidade bruta necessidade humana; seu idealismo é a fantasia, a arbitrariedade, o capricho. N enhum eunuco adula mais baixamente seu déspota ou procura com os meios mais infames estimular sua capacidade embotada de gozo, para granjear para si mais moedas e para fazer sair ovos de ouro do bolso de seus próximos, cristãmente amados" (1974: 157).

Importa salientar, de tudo isso, o profundo e plural desencontro de interesses, visões e perspectivas entre o mundo da produção do conhecimento, da arte, do jornalismo e da publicidade, só para ficar no âmbito da assim chamada comunicação de massa ${ }^{7}$, queretro-alimenta e atualiza permanentementeum imaginário coletivo já carregado desde tempos imemoriais com imagens ainda outras em torno do beber e da figura do bebedor.

\footnotetext{
Na contramão das abordagens convencionais, vale registrar o destaque crescente e cada vez melhor informado que vem sendo dado ao tema em diversas telenovelas, no Brasil.
} 
Assim, não causa estranheza que, no plano do senso comum, infinitas apropriações individuais e coletivas componham e recomponham essas visões e respectivas matrizes, ao amal gamá-las a outros e mais abrangentes influxos culturais. N esse plano ainda mais difuso, o pequeno e frágil acúmulo de conhecimento científico se perde por inteiro em meio a variações sobre o mesmo tema segundo as quais o bêbado é "uma sensibilidade especial eincompreendida pela mediocridadegeral"; uma boa carraspana "écoisa de macho" ou de "elementos deal ta periculosidade, pausquenasceram tortos" e que, portanto, é preciso "enfrentar com vigor e autoridade"; mas o descontrole no beber poderá ser também conseqüência da falta defé, purgação de pecados cometi dos em vidas anteriores, possessão por espíritos malignos ou apenas destino.

Certamente, a cada geração, centenas de milhares de al coólicos vêm se afogando nesse banhadão simbólico, movediço e sem fundo, agitado por correntes que os levam para todas as direções antes de tragá-los ${ }^{8}$. E aqui é momento de perguntar como é que AA - comunidade de alcoólicos auto-resgatados desse banhadão - lida com tal complexo de representações sociais e com os conflitos que essa rede simbólica estabelece com suas histórias de vida, com os fatos do seu próprio alcoolismo?

\section{A proposta de AA}

M uito resumidamente, podese dizer que a proposta de AA inclui: a) uma concepção de al coolismo como enfermidade "física, mental e espiritual", primária, progressiva, incurável mastratável ${ }^{9}$; b) a abstinência como précondição para a "recuperação" (esta última compreendida como qualidade de vida, ou seja, busca de toda e

\footnotetext{
${ }^{8}$ Seas estimativas da OSM quanto à incidência de alcoolismo são realistas, há mais de meio bilhão dealcoólicos no mundo. AAcalcula seus membros em 2 milhões; se somarmos a estes, com otimismo, outros 2 ou 3 milhões que se recuperam através de clínicas, programas públicos e privados, ou mesmo pela pertença a uma religião, chegaríamos a $1 \%$ do universo. 0 que acontece com os restantes $99 \%$ ?

${ }^{9}$ Compare-se com a definição da CID/10 - versão mais atual evigente do Código Internacional de Doenças da Organização Mundial de Saúde (apud Seibel e Toscano Jr. 2000: 228), que (tendo já substituído as expressões "alcoolismo" e "síndrome de abstinência alcoólica") definea "Síndrome de Dependência de Substância Psicoativa" (inclusive álcool) como "um grupo de fenômenos fisiológicos, cognitivos e da conduta pelos quais se indica que o uso de uma substância, ou de um tipo de substância, se tornou uma prioridade muito mais alta para 0 indivíduo que outros comportamentos que anteriormente tinham mais importância para ele. Característica descritiva dessa síndrome é o desejo (freqüentemente forte e, muitas vezes, irresistível) de consumir a(s) droga(s) de que se depende que pode(m) ou não ter(em) sido prescrita(s) por médico(s) ou álcool ou tabaco. Pode haver evidência clínica de que, quando do retorno ao uso da substância de que se depende, após um período de abstinência, verifica-se 0 aparecimento mais rápido das manifestações clínicas de dependência do que em pessoas não dependentes."
} 
qualquer condição capaz de tornar a existência significativa segundo os valores de cada membro); c) D oze Passos "sugeridos" para al cançar e manter tanto a abstinência como a recuperação; d) a pertença a um grupo de $A A$ - e a freqüência às suas reuniões regulares - como estratégia para a prática permanente dessa proposta; e) outros dois conjuntos de princípios, intitulados D ozeTradi ções e D oze Concei tos para Serviços M undiais, os quais estabel ecem o desenho institucional da associação, configurando normas e práticas de convivência singulares as quais, em conjunto com a prática dos Passos, materializam a cultura (institucional) de Alcoólicos Anônimos ${ }^{10}$.

Embora não seja possível, nos limites desse texto, aprofundar todos esses elementos constitutivos da proposta e da cultura de AA, al guns aspectos precisam ser pontuados. Para começar, vale ressal tar quea associação desenvolveu uma vi são abrangente do fenômeno do alcoolismo, incorporando o modelo médico mas indo além dos reducionismos vigentes à época do surgimento e consolidação do movimento de ex-bêbados. Assim, embora não tenham utilizado tal expressão, os anônimos levaram em conta a dimensão cultural do alcoolismo e sua interpenetração nas culturas locais e no imaginário dos al coólicos, desenvolvendo um conjunto de atitudes muito cautelosas de abordagem do problema, de modo a não entrar em conflito com as arraigadas, plurais e contraditórias crenças e hábitos etílicos constitutivos dos incontáveis contextos culturais nos quais vieram ramificando sua existência.

Por outro lado, a proposta deAA precisou ser abrangente o suficiente para ensejar, além da abstinência etílica, uma profunda mudança de visão (sobre seus hábitos de beber, sobre os fatos de sua história de vida, val ores, conceitos, crenças, perspectivas, relacionamentos e pertencimentos sociais etc) e ainda, uma profunda mudança do seu modo devida, contando, para tanto, com o singular modo de convivência proporcionado pela pertença a um grupo de AA (conforme veremos adiante)

Além disso, toda a proposta dos AAs tem como base práticas comunicativasfundadas no resgate do sujeito, superando a incomunicação também característica do alcoolismo $^{11}$. Alcoólicos Anônimos nasceu da comunhão entre seus primeiros membros, da

\footnotetext{
${ }^{10}$ Para conhecer na íntegra 0 enunciado dos Passos, Tradições e Conceitos de AA, vide os anexos da tese de doutorado da autora (Ganev, 2002), ou consulte-se a bibliografia da própria entidade, ou ainda sua home page: uww.alcoolicosanonimos.org.br.

${ }^{11}$ De fato, há uma relação direta entre estágios mais avançados da enfermidade e a incapacidade de estabelecer comunicação não-patológica consigo mesmo e com o mundo externo. Quanto mais a vida fica centrada no beber, mais o bebedor tem prejudicada sua própria percepção do mundo e do outro, passando a sistematicamente mentir, ocultar, minimizar, racionalizar, negar, manipular informações, a ponto de perder a identidade ea noção do real. Para maior aprofundamento, ver Vaillant (1999).
} 
possibilidade de expressarem entresi seu profundo desejo pela vida epela superação do próprio alcoolismo. D esde seus primeiros encontros e conversas, e desde seus primeiros vislumbres de que seus achados poderiam ser socializados e úteis a outros iguais a eles, toda a sua preocupação esteve e permanece vol tada para a preservação das formas de comunicação intersubjetivas que foram construindo desde quando não passavam de umas poucas dezenas de membros: a abordagem e as reuniões.

A assim chamada "abordagem" dos AAs consiste no encontro preferivelmente planejado entre um alcoólico em busca de ajuda e outro que já está reconstruindo sua vida num grupo da associação. Seu fundamento éque sua real ização surte efeitos profundos tanto sobre 0 abordado quanto sobre 0 abordador, porque opera aí um "efeito espelho" a partir do qual ambos podem ver-se a si mesmos no outro: o bêbado ouve seu próprio passado no relato do agora sóbrio e mal acredita (mas passa a desejar) que sua vida poderia algum dia ficar parecida com a da pessoa desconhecida que, no entanto, está a Ihe contar, com simplicidade e verdade, detalhes sobre seus horrores, desejos e atuais estratégias de bem viver. Enquanto isso, o membro de AA revive uma vez mais seu antigo modo de ser, materializado na presença do outro, e recria suas representações do processo do seu auto-resgate, potencializando-o.

E as reuniões tratam de coletivizar essa comunhão inter-pessoal, criando dinâmicas nas quais o grupo funciona como comunidade de ouvintes e cada membro se torna aprendiz de narrador, oferecendo seus relatos pessoais com a segurança de que não será interpelado e nem julgado, mas apenas ouvido e provavelmente compreendido pelos que percorreram trajetórias similares, seguem passando por dificuldadese desafios igualmente similares na aventura de reaprender a viver e, no instante seguinte, passarão à condição de narradores, enquanto aquele que acabou de falar retorna ao duro aprendizado de ouvir isenta e solidariamente.

Por fim - e aqui entramos no aspecto central desse texto - era preciso dar forma institucional a esse movimento de ex-bêbados, de modo a não perder a qualidade intersubjetiva ( para eles, vital) de suas práticas comunicativas, qualificá-lo como um interlocutor aceitável no campo dos estudos sobre alcoolismo (não-científico, mas legítimo, organizado, dotado de espírito cooperativo e de um saudável empirismo), permitir uma divulgação massiva de sua proposta e, para tanto, garantir-Ihe plasticidade suficiente para acolher alcoólicos em busca de ajuda independentementedequais quer outras condições. Como, afinal, AA equacion ou seus impasses organizativos?

\section{Um modo de convivência singular, singularmente forjado}

N os onze primeiros anos de sua existência (1935 a 1946), AA viu-se às voltas com inúmeros problemas e dificuldades decorrentes de sua própria expansão, pri- 
meiro dentro dos Estados Unidos e C anadá, depois também em outros países e continentes. Problemas ligados à formação dos seus grupos sob circunstâncias as mais inusitadas, à sua sustentação financeira e coesão interna, aos requisitos para tornar-se membro eàs relações inter-grupose com a comunidade/sociedade, os quais chegavam ao conhecimento dos co-fundadores principalmenteatravés decartas enviadas por indivíduos e grupos recém-formados. As respostas sempre personalizadas a essa volumosa correspondência - analisadas ediscutidas por um grupo pequeno, coeso e pragmático de pessoas - , cujo fluxo durou cerca de dez anos, associadas também ao conhecimento mais técnico de alguns pioneiros profissionalmente ligados ao mundo das organizações comerciais, formaram a base principal para a formulação das Tradições (e, posteriormente, dos Conceitos) de AA, que em 1946 foram sistematizadas e publicadas pela primeiravez, enunciando as soluções genéricas encontradase doravante sugeridas a todos os grupos, para fazer frente àquelas dificuldades.

A seguir, apresento uma síntese do que pude compreender a respeito desses princípios que, a um só tempo, configuram em linhas gerais a estrutura, mas também a cultura institucional de Alcoólicos Anônimos, afetando profundamente o modo de convivência de seus membros:

- Unidade: as Tradições começam afirmando que a unidade de cada grupo, bem como entre os grupos e na entidade em geral, é crucial para a recuperação individual: "sem o grupo, o indivíduo perece", portanto, "o bem estar comum deve vir em primeiro lugar" (Primeira Tradição). N a verdade, trata-se de uma declaração ideal cuja real ização estará na dependência direta da prática dos demais princípios;

- N ão-governo (Segunda Tradição): nenhum indivíduo tem poderes para governar, nenhum encargo permite impor o que quer que seja e não há sistema de direitos/ deveres e sanções pelo qual alguém possa ser punido ou expulso. É também um princípio cuja efetividade é dada pelas demais tradições (especial mente a Terceira, Sétima e D écima Segunda, como veremos) e resulta dele que alcoólicos pertencentesa qual quer elite (seja por poder político ou econômico, status, fama, carisma, intelecto, habilidades técnicas, liderança religiosa ou qualquer outro elemento que comumente coloca pessoas em situação de privilégio), podem em AA apenas tanto quanto quaisquer outros membros (ao contrário do que costuma ocorrer em associações de natureza social). 0 corre então um nivelamento pel o humano, todos são iguais na medida em que são gente que sofre circunstâncias comuns e deseja em comum um outro conjunto de circunstâncias;

- Associação individual incondicional (TerceiraTradição): não hárequisitospara ser membro, a não ser um impal pável "desejo de parar de beber". O s membros afirmam não 
temer o passado de quem está chegando, até porque al coolismo não produz cidadãos respeitáveis. Além disso, não é preciso admitir-se al coólico e nem que o citado desejo exista já nos primeiros contatos dos potenciais futuros membros com a entidade: cresce, por exemplo, o número dos que são enviados a um grupo por força de decisão judicial para cumprir penas alternativas, e acabam despertando e se recuperando;

- Autonomia dos grupos em assuntos que não afetem AA em seu todo (Q uarta Tradição): diz respeito ao processo detomada de decisões, que só pode ser melhor compreendido com um conhecimento mais pormenorizado dos váriosníveis da estrutura de AA num dado país. Segundo pude compreender, o principal éque cada grupo, enquanto entidadeinformal (sem existênciajurídica), de fato não pode ser forçado a nadae, pelo contrário, podesimplesmentedeixar definanciar asinstâncias mais abrangentes (regionais, estaduais, nacionais e internacionais, 100\% dependentes desse financiamento) se vier a discordar profundamente das orientações mais gerais, em cujas definições toma parte por um minucioso e intenso mecanismo de participação. E é de fato livre para tomar suas próprias decisões. M esmo a ressalva contida no enunciado da Tradição não tem força para se impôr e, além disso, AA tem uma política de não-defesa (detalhada num de seus Conceitos) que desestimula a entidade de "cobrar" o que quer que seja de quem quer que seja, interna ou externamente, e até mesmo de se defender publicamente de eventuais ataques que venha a sofrer (distorções de sua proposta, uso indevido de seu nome etc);

- Um só objetivo insitucional, na verdade dois, mas vistos como tão indisso-ciáveis entre si que foram formulados como "único": preservar a sobriedade dos membrose "transmitir a mensagem de AA ao alcoólico que ainda sofre" (Q uinta Tradição). São metas sem dúvida particulareselimitadas, bastanteadequadas, portanto, à comprometida capacidade de compreensão dos que "ainda estão por chegar" aos grupos; politicamentefalando, adequam-setambém ànecessidadede união erelações internas harmônicas num universo multiplamenteheterogêneo, fisgando a todospelo quena verdadeéseu ponto comum vital. Tal timidez de objetivos opera também (sempre associada às demais Tradições) na evitação dos problemas institucionais convencionais, porque supersimplifica suas rotinas e necessidades quanto a recursos materiais, humanos e organizacionais para concretizá los. Por fim, aquela comunicação profunda, inter-subjetiva, é colocada como a razão da existência da entidade em todo 0 mundo ${ }^{12}$. Tudo, na entidade, gira em torno do

\footnotetext{
${ }^{12}$ No Manual de Servicos está escrito que "um serviço em AAétudo aquilo quenos ajuda a alcançar uma pessoa que sofre - o chamado Décimo Segundo Passo propriamente dito - pelo telefone ou por uma xícara de café, como também pelo Escritório de Serviços Gerais de AApara a ação nacional" (op.cit, p.13).
} 
aperfeiçoamento dessa capacidade comunicativa, eas demaisTradiçõesseencarregam de reduzir os principais riscos de que assim não seja;

- N ão-afiliação (Sexta Tradição): trata-se de um desdobramento do princípio anterior, pelo qual se determina o tipo de relações inter-institucionais que a entidade adotará como política, e que podem ser definidas como relações de cooperação com independência. Ao "jamais sancionar, financiar ou emprestar o nome" a quaisquer instituições e final idades "alheias", AA materializa o princípio anterior efaz jusà imagem que pretende oferecer aos olhos dos ainda bêbados: de isenção (política, religiosa, étnica etc) - eliminando pretextos para a racionalização al coólica (um alcoólico ateu não se aproximará de AA se suspeitar, mesmo equivocadamente, que a entidade é religiosa). Eis al guns exemplos que observei durante a pesquisa de campo: quando vão divulgar o grupo numa missa da paróquia do bairro, osAAs se privam de participar dos ritos da missa, mesmo sendo católicos; poderão manter um grupo funcionando em sala cedida por uma escola, mas não participarão estruturalmente do seu Conselho; como indivíduos, sentem-selivres para tomar parte em quaisquer empreendimentos, mas, nesses casos, manterão anônima sua condição demembros deAA; farão contatose cooperarão com a administração municipal, independentemente da sua orientação política, mas não manterão relações diretas com nenhum dos partidos. Tal vigilância constante sobre a natureza de suas relações externas os têm mantido livres de "problemas de dinheiro, propriedade e prestígio";

- Auto-suficiência financeira (SétimaTradição): éo equivalente material dos princípios de não-governo, autonomia e não-afiliação. Tudo o que AA realiza é financiado apenas por seus membros, e aquilo que estes não podem financiar não é realizado, para evitar ingerências externas. Além disso, as contribuições são anônimas e os membros são orientados a contribuir com valores compatíveis com a realidade sócio-econômica de cada grupo, para evitar ingerências internas: a instituição não aceita, por exemplo, herança de membros fal ecidose sugeretetos individuais anuais. O s grupos e escritórios praticam assim um "princípio de pobreza coletiva": não têm sede própria nem patrimônio, operam com o estritamentenecessário à realização de seus serviços e, no caso dos grupos, quaisquer obrigações legais são assumidas por um ou dois membros (contratos de aluguel, titularidade de contas bancárias e a pagar etc); finalmente, a "política financeira" ideal é assim formulada: "tão apenas as despesas correntes mais uma reserva prudente" (equival ente a três meses de despesas, para emergências e imprevistos). Tal política de operar sempre no limite vivifica as relações internas e externas porque praticamente obriga as lideranças a darem o seu melhor na busca de uma administração sóbria, eficiente e democrática, ou seja, 
induz a auto-fiscalização ao invés dearmar-secom um excesso denormasfiscalizadoras e punitivas, já que permanece implícito que a ineficiência, o esbanjamento ou 0 autoritarismo poderiam levar à recusa dos membros em contribuir, comprometendo a viabilidade institucional. Além disso, afasta naturalmente lideranças potencialmente "perigosas", pois, em princípio, ninguém queesteja interessado em locupletação se sentiria atraído pel os "orçamentos" de um grupo de AA, inversamente proporcionais ao volume de trabalho voluntário implicado em sua manipulação (eé dos grupos que tais lideranças sai rão mais tarde para "servir na estrutura", isto é, em suas instâncias mais abrangentes, cujos orçamentos são maiores) ${ }^{13}$;

- N ão-profissionalismo (O itava Tradição): trata-se do caráter voluntário e gratuito na realização do "propósito único" da entidade, isto é, na "transmissão da mensagem" aos ainda bêbados, esclarecendo-se que, por outro lado, nada impede que alcoólicos e não-al coólicos sejam contratados eventualmente por AA para a prestação de serviçosoutros, osquais exijam qualificação profissional específica, assim como nadaimpede que AAs sejam contratados por outras instituições por conta de sua experiência no campo do alcool ismo - apenas se sugere que, neste caso, mantenham no anonimato sua condição de membros da associação. Ao mesmo tempo em que desdobra 0 princípio de não-afiliação no plano individual, a $O$ itava Tradição também lida com as delicadas questões do dinheiro e do prestígio, prevenindo o risco de que al guém tire proveito de sua vinculação com AA - nas raras vezes em que isso acontece, a má fé se beneficia do desconhecimento da sociedade sobre o funcionamento de AA

- N ão-organização (N ona Tradição): complementar aos princípios de não-governo e autonomia, estabelece a ausência de hierarquias no que se refere a poder demando, mas não no que se refere a serviço, resultando numa combinação de sub e autoregulação. As instâncias maiores de AA não o são por serem mais poderosas ou deliberativas, mas porque são mais abrangentes geograficamente e necessárias em termos operacionais. É aqui que as Tradições formam com os Passos - e com a condição de al coolismo dos membros - uma totalidade indissolúvel: assim como o membro que não aceita os Passos estará, muitas vezes, "assinando sua própria sentença demorte", o grupo quenão tem "uma boa aceitação" dasTradições poderá "também deteriorar-se e morrer". Eis a conclusão dos pioneiros:

\footnotetext{
${ }^{13}$ Os problemas com tesoureiros são espantosamente raros ( mais ainda pelas circunstâncias econômico-culturais do país e pela falência material que caracteriza ex-bêbados) e, no Brasil, segundo os membros mais antigos, pertencem cada vez mais ao passado, "quando os grupos ainda não se pautavam pelas Tradições".
} 
$N$ ós de AA obedecemos a princípios espirituais, primeiramente porque é preciso e em segundo lugar porque acabamos gostando do tipo de vida que tal obediência acarreta. Grande sofrimento e grande amor são os disciplinadores de AA; não precisamos de quaisquer outros ( 0 s D oze Passos... p. 158)

- N ão-controvérsia pública (D écima Tradição): desdobra e assegura os princípios de unidade e propósito único. U ma vez mais, os indivíduos são livres para posicionaremse publicamente em relação a quaisquer temas e questões, mas, nesses momentos e espaços, sugere sequeomitam sua condição deAAs. Pelo contrário, quando eaonde estiverem a serviço da entidade, deverão abster-se de qualquer posicionamento ou opinião, independentemente das reações que sua omissão possa gerar.

- Atração ao invés depromoção (D écima PrimeiraTradição): estabelece uma política de relações públicas segundo a qual toda publicidade deve recair sobre a entidade e sua atuação (e não sobre a identidade de seus membros), e, de preferência, ficar por conta deterceiros - os assim chamados "amigos de AA" no campo da comunicação, ciência, educação eoutros. A entidadetomainiciativas de cooperação junto à comunidade e à sociedade e, nesse sentido, divulga a si mesma numa base de atração: 0 impacto pelas histórias devida dosmembros, a ausência de pedidos deajudafinanceira, a divulgação dos serviços (voluntários) mas não das identidades, resultam em credibilidade e aceitação junto ao público. A ausência de publicidade padronizada acrescenta exigências à recuperação individual ecoletiva (dosgrupos), poisse enfatiza que a imagem de AA numa dada comunidade corresponderá à imagem daqueles que, ali, querendo ou não, "representam" Alcoólicos Anônimos;

- Anonimato (D écima Primeira e D écima Segunda Tradições): dizem os AAs que este é seu "alicerce espiritual", o fundamento da superação do egocentrismo preexistente ou agravado pelo al coolismo (embora não de um desejável tipo de egoísmo). As implicações práticas e subjetivas desse princípio são muitas. Cada membro é orientado para: a) manter "cem por cento" de anonimato individual em qualquer mídia; b) desenvolver autonomia para decidir em que circunstâncias e com que critérios fará "discretas revelações" (a familiares, colegas de trabal ho etc) ou abrirá mão do anonimato em situações semi-públicas, como palestras (nesse caso, os ouvintes são solicitados a respeitar o anonimato do pal estrante, abstendose de identificá-lo pelo nome completo e/ ou por imagem); c) respeitar o direito ao anonimato de seus "companheiros" (cada qual é livre perante 0 anonimato próprio, mas não 0 alheio), abstendo-se de revelar a identidade e a história de quaisquer outros membros; d) cultivar o anonimato como elemento dehumildade, dentro e fora deAA, evitando alardear sobre o serviço que presta, as contribuições que 
faz, os pormenores de sua condição profissional, financeira, política ou quaisquer outras formas de distinção pessoal.

Diversostítulos da bibliografia oficial de AA, incluindo livros, livretes, folhetose vídeos, além dos estatutos e regimentos de seus escritórios regionais e nacionais, dedicam-se a transformar em organização, rotinas e procedimentos as generalidades "sugeridas" pelas D ozeTradições. A maior parte dos muitos eventos regionais e nacionais periódicos da entidade têm a mesma finalidade.

M ais de vinte anos após a aprovação e adoção das Tradições, quando Alcoólicos Anônimos já tinha uma realidade internacional consolidada, foi escrito um último conjunto de princípios, aliando os aprendizados daqueles anos de prática de relações internacionais a idéias extraídas das teorias de organizações comerciais então em voga - quer incorporando, quer rejeitando certas características organizativas do mundo empresarial. A vivência de um dos co-fundadores no mundo dos negócios, a origem empresarial demuitos dos membros pioneirose "amigos não-alcoólicos" que apoiaram einfluenciaram a entidade em seus primórdios nos Estados U nidos, constituíram as fontes de inspiração dos D oze C onceitos para Serviços M undiais de AA.

Trata-se de um texto mais denso e técnico, quetraduz o espírito das Tradições para as instâncias e relações mais abrangentes da entidade: define responsabilidades, competências, critérios, direitos e limites das lideranças e instâncias nacionais e internacionais. Os Conceitos detal ham as atribuições da C onferência $\mathrm{N}$ acional, da Junta de Custódios, dos Diretores e funcionários do escritório nacional; propõem e definem três direitos básicos- os quaistambém encontram aplicação prática nos grupos, distritos e escritórios regionais: D ireito de D ecisão, de Participação e de Apelação (este como um recurso para eventuais minorias ou indivíduos que se sintam prejudicados por decisões tomadas); descrevem as características subjeti vas desejávés para as lideranças e propõem métodos cui dadosos para sua escolha; e definem princípios de equivalência entre autoridade e responsabilidade, al ém de rodízio na realização dos serviços.

Afirma-se que tais Conceitos oferecem seis "garantias" da aplicação do "espírito das Tradições" às macro-relações de AA: que a Conferência (nacional) "nunca se torne sede de riqueza ou poder perigosos"; que "suficientes fundos para as operações, mais uma ampla reserva, sejam o seu prudente princípio financeiro"; que "nenhum dos membros da Conferência seja colocado em posição de autoridade absoluta sobre qual quer um dos outros"; que "todas as decisões importantes sejam tomadas através de discussão, votação e, sempre que possível, por substancial unanimidade" (SIC); que "nenhuma ação da Conferência seja jamais pessoal mente punitiva ou uma incitação à controvérsia pública"; e que, "embora a Conferência preste serviço a Alcoólicos Anônimos, ela nunca desempenhe qualquer ato de governo e que, da mesma 
forma que a Sociedade de Alcoólicos Anônimos a que serve, a Conferência permaneça democrática em pensamento e ação".

G rupos deAA organizadosa partir desse conjunto de princípiosacabam ganhando um desenho paradoxal, uma vez que se configuram aum só tempo como coletividades absolutamente informais e autônomas entre si, mas minuciosamente organizadas e articuladas umas às outras, tanto mais sub-reguladas quanto mais auto-regulados vão se tornando seus participantes. N os grupos melhor estruturados, cria-se um modo de convivência dinâmico e conflitivo, marcado pela variedade de atividades e responsabilidades, cujas rotinas aparentes não diferem das de qualquer organização humana, masganham papéis esignificadossingulares por estarem indissociavelmente ligadas ao contexto de auto-resgate individual, de transformação do modo de vida dosmembros. Pois o mesmo efeito-espel ho queacontecena abordagem inter-individual e nas reuniões regulares ganha concretude e conflitividade quando se trata de agir col etivamente: cada qual pode notar facilmentelimites e potencialidades al heios, expostos no fervilhante cotidiano coletivo, eisso ajuda poderosamente a auto-observação naqueles tempos e espaços projetados para tal finalidade. As confrontações entre "teoria e prática" são constantes, de todos os tipos e intensidades, repercutindo em aspectos diferentes para diferentesindivíduos eimpulsionando o desenvolvimento de sua(s) subjetividade(s) - compreendida(s) aqui como conjunto(s) de sensibilidadesecapacidadeshumanas ${ }^{14}$. D entre estas, convém assinal ar a tolerância, prérequisito para se conviver com diferenças culturais.

U ma outra faceta da aventura dos ex-bêbados que tem relação direta com sua capacidade de acolher e trabal har a diversidade cultural refere-se à qualidade do seu processo de formalização ${ }^{15}$ (para além das características institucionais vistas até aqui e que resultaram desse processo). D esse ponto de vista, é interessante notar que:

- cada um dos problemas com os quais AA teve de se defrontar para sobreviver enquanto instituição constituiu-se como uma polarização dicotômica composta por um par de soluções simetricamente excludentes e quase sempre redutíveis à

\footnotetext{
${ }^{14}$ Para aprofundamento do conceito de subjetividade, ver Ganev (2002).

${ }^{15}$ Noção proposta por Boaventura de Souza Santos (1991), que faz uma instigante análise dos padrões de organização social orientados pela racionalidade cartesiana ainda contemporânea. Caracteriza-os como construções dicotômicas cujos opostos, em última instância, podem ser sempre vistos como formalismo absoluto e informalismo absoluto, de modo que os atores sociais oscilam, com movimentos pendulares, entre um e outro desses extremos. Para 0 autor, tal sistema estaria entrando em colapso. Um estudo mais demorado sobre essas reflexões pode ser encontrado nos anexos da tese da autora (Ganev 2002).
} 
oposição formalismo absoluto versus informalismo absoluto (por exemplo: buscar muito dinheiro ou recusar-se a lidar com ele; estabelecer regulações internas minuciosas e rígidas ou a anarquia pura e simples; lançar mão de publicidade convencional ou manter-se em clandestinidade);

- os grupos nascidos durante os primeiros dez anos de existência de AA (nos Estados U nidose, depois, em outros países) movimentaram-se cotidianamente como pêndulos, indo de um a outro extremo no modo de fazer frente a seus dilemas organizativos, praticando todo tipo dealternativas práticas, desde as mais radicais até as mais comedidas, até que a Tradição correspondente fosse fixada;

- cada resposta finalmente "sugerida” pelas Tradições e Conceitos constituiu-se como solução de compos ção que possibilita a neutralização sempreprovisória dos pólos dicotômicos por meio de um frágil equilíbrio, passível de ser rompido pela força sempreviva dequalquer um dos pólos. Trata-se, portanto, de um equilíbrio carente de mediação complexa porqueprecisa construir-see permanecer significativo eminucioso, mas só pode ser mantido por sujeitos até então marcados pela desagregação, superficialidade einconstância.

Em outras palavras, para sobreviver como instituição, AA precisou render-se ao elemento caótico do seu próprio processo de formação e inventar, para si mesma, contornos que permitissem a tal elemento não-linear emergir sempreelivremente, a fim de que pudesse ser auto-regulado (pelos indivíduos, pel os grupos e pelas demais instâncias da associação).

Entendo que esse processo, a um só tempo de expansão e estruturação, configurou-se como uma apropriação leiga e coletiva do método científico, porque consistiu numa longa experimentação coletiva comparada, sempre resolvida a partir de um crité rio pragmático - adotar o que funciona, descartar o que não funciona (do ponto de vista da preservação da comunicação inter-subjetiva) - e de uma também paradoxal relativização dasregulações, todas elas formuladas como meras "sugestões", dependentes das (humanas) decisões de cada grupo.

Configurou-se ainda como um processo comunicacional: até a formulação final das Tradições, um dos co-fundadores escreveu artigos contendo esboços e proposições provisórias, os quais eram publicados na Grapevine - que já circulava como revistanorte-americana (posteriormenteinternacional) deAA. Tal divulgação preliminar conferiu interatividade à formulação das Tradições, uma vez que os grupos de então reagiram, discutiram, se rebelaram ou incorporaram as propostas ainda em exame, reorientando ou corroborando sua formulação final ${ }^{16}$.

Juntas, essas dimensões de experimentação coletiva ede interati vi dade comunicativa parecem ter sido co-responsáveis pela natureza compósita e plástica das Tradições 
e dos Conceitos, queentão puderam ser apropriados "já-prontos" por ex-bêbados das mais diversas culturas.

Aqui, há dois pontos a destacar, ambos pertencentes àquele tipo de evidências que não se mostram facilmente e ambos com fortes implicações sobre a modelagem local de AA, portanto, sobre suas potencialidades e limites no que se refere a lidar de modo humanizado com a diversidade cultural de seus membros. Primeiro, o processo de sua chegada e recriação em outros tempos e espaços difere necessariamente do de sua "invenção" coletiva original num aspecto essencial no contexto da presente reflexão: as soluções institucionais fundamentais já estão dadase, por muito humanizadas que sejam, aqueles que ora as empregam não precisaram desentranhá-las da própria experiência, vale dizer, de suas especificidades em última instância culturais. Além disso, tais especificidades (que provavelmente produziriam resultados outros se se tratasse de reinventar a entidade em cada lugar) modificam mais ou menos acentuadamente os el ementos já-dados de $\mathrm{AA}$, ao levá-los à prática.

A fim de discutir com mais detal he esse ponto, será interessante recorrer a al guns dados do trabal ho de campo, o que será feito a seguir.

\section{AA à brasileira e à uruguaia}

Começaremos observando o modo como Alcoólicos Anônimos chegou e se implantou no Brasil e no Uruguai, porém, o enfoque histórico é tomado aqui apenas como ponto de apoio e por isso não será aprofundado. D entre apontamentos e informações recol hidos na pesquisa bibliográfica e no trabal ho de campo, apresento a seguir aqueles que considerei significativos nesse sentido:

\footnotetext{
${ }^{16}$ Experimentação e interatividade marcaram também a elaboração do livro Alcoólicos Anônimos entre 1939 e 1941 ( o primeiro do movimento de ex-bêbados) no sentido de proporcionar uma leitura "clara e precisa" mesmo em culturas muito diferentes e regiões longínqüas, nas quais "Levaria muito tempo para que os leitores (...) pudessem ser contatados pessoalmente”. Alinguagem mereceu atenção especial. Após meses de incessante revisão crítica coletiva nos dos dois grupos então existentes (em Nova Iorqueeem Akron), quatrocentas cópias foram mimeografadas e enviadas a lideranças de distintas religiões e campos do conhecimento, incorporando críticas e sugestões ao texto final. Em parte por conta dessa comunicação-para-a-inclusão, a democracia existente em AAse projeta externamente como perspectiva de inclusão potencial da diversidade. Olivro demorou 35 anos para atingir a marca do primeiro milhão de exemplares vendidos, mas a distribuição em língua inglesa alcança hoje um milhão de exemplares/ano, o texto já foi editado em 40 idiomas e é distribuído em cerca de 140 países.
} 


\section{Brasil: primeiros contatos}

Em 1946, um norte-americano vem passar três anos no Brasil por motivos profissionais. Apósintensa troca de correspondência com AAEU A, forma-se um pequeno grupo no Rio de Janeiro, com reuniões em língua inglesa, nas casas de seus membros. Em 1949, já com brasileiros (apelidados de "os doze desidratados"), há reuniões semanais numa sala da ACM do Rio de aneiro. Em 1956 havia 13 grupos registrados no catálogo mundial de AA e, no início dos anos 60, "aproximadamente vinte grupos espal hados por vários estados". Em São Paulo o primei ro grupo surgiu em 1965.

\section{Uruguai: primeiros contatos}

No começo dos anos 40, o psiquiatra uruguaio Chans $C$ aviglia vai aos Estados Unidos e conhece Bill W. Na volta, inicia um grupo em M ontevidéo, mesclando técnicas de terapia de grupo e princípios de AA. Nos anos 60, alcoólicos que já conheciam AA criam a ADEA (Amigos D el Enfermo Alcohólico), que também ajuda a divulgar as idéias de AA. Em 1974, al coólicos oriundos dessas iniciativas começam a reunir-se como um grupo de AA No mesmo ano, forma-se outro grupo em Punta D el Leste, a partir do apadrinhamento de AAs argentinos em férias na região. $\mathrm{N}$ os anos seguintes, surgem grupos em vários $\mathrm{D}$ epartamentos.

$\begin{array}{lll}\text { Primeiras ações ORganizat IVAS: } & \text { BrasiL } & \text { U RUGUAI } \\ \text { Primeiros grupos no país } & 1956 & 1974 \\ \text { Primeiro acesso ao Livro Azul: } & 1971 & 1971 \\ \text { Primeira edição local do } & & \\ \text { M anual de Serviços: } & 1987 & 1983 \\ \text { Primeira Conferência: } & 1977 & 1982 \\ \text { Primeira Junta de Custódios: } & 1984 & 1978 \\ \text { Primeiro escritório: } & 1970 & 1979 \\ \text { Revista Vivência eTriangulo } & 1985 & 1985 \\ \text { Home page: } & 1999 & 1996\end{array}$

(Ganev 2002)

Para começar, será interessante notar que, ao contrário do que aconteceu no U ruguai, onde o surgimento dosgrupos edas estruturas locaise nacional podeancorar-se na bibliografia básica da associação já editada (nos Estados Unidos) em espanhol (vale dizer, no conhecimento da trajetória dos ex-bêbados norte-americanos e 
das soluções que encontraram e propuseram), no Brasil os títulos em língua portuguesa só começaram a ser editados quando já havia uma quantidade significativa de grupose, inclusive, uma incipiente estruturação inter-regional ("aprovada em cartório" desdeo início dos anos 50). O u seja, os primeiros membros brasileiros basearam sua construção coletiva nas noções pessoais de AAs norte-americanos aqui radicados ou de passagem, e em fragmentos de traduções não-oficiais.

Cabe acrescentar a bibliografia de AA foi ampla e longamente ignorada e/ou rejeitada pelos pi oneiros brasileiros (osmotivosforam váriose conjugados: 0 anal fabetismo, a aversão à leitura, a ideologia do anti-(norte)americanismo em alta nos anos 60 a 80 e, certamente, o estranhamento frente a princípios oriundos de uma cultura multiplamente diferente).

$\mathrm{N}$ ota-se ainda que no $\mathrm{U}$ ruguai houve uma relativa simultaneidade entre os eventos organizativos marcantes da estruturação nacional (conferência, eleição da Junta de custódios e estabelecimento de escritório com divulgação pública) e a primeira sistematização dessa estrutura sob a forma do "M anual de Serviço" - que pode ser tomado como representação da compreensão coletiva local em torno dos princípios elaborados pelos AAs norte-americanos nos anos 30 e 40, eainda, como "tradução"I adaptação de tais princípios às realidades locais - enquanto que no Brasil a primeira edição do "M anual" foi bastanteposterior àqueles eventos, tendo incorporado aspectos organizativos locais inexistentes na proposta original.

Finalmente, cabe salientar que, no U ruguai, a duradoura iniciativa do psiquiatra Chans $\mathrm{C}$ aviglia parece ter resultado, no que se refere à prática dos pi oneiros de $\mathrm{AA}$ naquele país, numa interpenetração profunda entre a proposta da associação e as práticas clínicas então adotadas por esse profissional.

Tal conjunto de circunstâncias iniciais certamente concorreu para definir diferenças na estruturação e no perfil de AA em ambos os países, as quais não serão pontuadas nem discutidas aqui, pois dizem respeito ao cotidiano dos grupos e exigiriam um trabal ho muito extenso de contextualização, o que foge aos objetivos e limites desse artigo. Pretendo apenas apresentar alguns elementos mais genéricos relativos às relações entre a cultura de AA e as culturas locais, tal como foram apreendidas por ocasião da pesquisa, tendo como pano de fundo a questão da integração latinoamericana, circunscrita ao microcosmo da aventura coletiva dos AAs.

\section{Etno-relatividade}

U ma primeira característica a destacar (e que diz respeito a Alcoólicos Anônimos como um todo), refere-seà diversidade humana presente em qual quer grupo de AA, que confronta seus membros, de forma direta e imediata, com o problema da dife- 
rença cultural (econômica, política, ideológica, religiosa, étnica, etária, educacional, sexual, física, educacional etc) e opera na direção de um significativo ataqueao etnocentrismo em geral e às incontáveis micro-formas de preconcei to e estereotipia.

0 contato com jeitos diferentes de viver, com indivíduos que professam val ores, crenças e pertencimentos diferentes, propicia um processo de tomada de consciência (não apenas racional, mas afetivo) dequeos preconceitos são produtos deum aprendizado remoto deconstruções coletivas (regionais, religiosas, políticas etambém temporais). Tal conscientização permite aos AAs relativizar seus próprios valores, visões e vivências, ou seja, desconstruir o caráter hierárquico e ameaçador das diferenças, substituindo-o por uma valorização destasúltimas, que passam a ser encaradas como alternativas, como riqueza humana.

A atitude etnocêntrica(Ver: Rocha 1994) não resiste à dinâmica das reuniões de grupo, na qual o diferente tem voz e identidade e, por isso, sua presença permite 0 "aprender a ouvir", isto é, acompanhar e compreender o movimento do outro, nos termos do outro - a título de exemplo, val elembrar queo ambiente de comunhão profunda de uma das reuniões que acompanhei no U ruguai, à qual estavam presentes um professor zen-budista, vários trabalhadores portuários, uma dona-de-casa, um morador de rua e um jovem que estava lá pela primeira vez, além de outros membros, é lugar comum mesmo nos grupos menos estruturados de qual quer país.

D essa forma, o etnocentrismo que, em maior ou menor grau, ainda marca 0 imaginário eas práticas sociais praticamente em todo o mundo, não encontra espaço nos grupos de AA, onde a convivência com tantas e tamanhas diferenças faz aflorar um senso de etno-relatividade (não no sentido estrito de etnia, mas no da diferença cultural em geral).

\section{“Dentro" e "fora" de AA}

Há quem acredite, por outro lado, que Alcoólicos Anônimos gera uma outra forma de exclusão, por delimitar muito rigidamente suas próprias fronteiras, cabendo então entrar no mérito desse questionamento, até porque tal delimitação acontece de fato com muita força nos grupos e aparece com espontaneidade na própria linguagem cotidiana: os não-AAs são chamados de "paisanos", "os outros", "quem não édo ramo", enquanto qualquer exteri oridadeéevocada como "láfora", "o mundão lá fora", o "dessa porta para fora" e assim por diante.

D entro do que foi possível apreender durante a pesquisa, o modo como os AAs significam e vivenciam essas fronteiras não aponta na direção do sectarismo e da intolerância. Sinaliza antes uma profunda val orização desse seu pertencimento específico, frente à riqueza de apropriações eventualmente dadas através dele. 
É o queindicam as respostas dadas a duas perguntas do questionário utilizado no estudo, eque trago como ilustração: metade dos AAs brasileiros e $80 \%$ dos uruguaios que o responderam afirmam comunicar-se melhor "dentro" deAA, em comparação com as pessoas "de fora". Q uando Ihes pedi para darem seus motivos, obtive como retorno as respostas a seguir (que eu mesma anotei, tomando o cuidado demanter as fal as e usos da língua dos participantes):

\section{No Brasil}

A linguagem que nós temos, no AA há facilidade. As pessoas fora não aceitam a nossa língua.

Porque há mais intimidade, formamos uma segunda família, podemos falar sobre estar sóbrio.

$M$ ais facilidade, as pessoas de AA me entendem, não criticam e procuram ajudar, pessoas de fora levam prum lado diferente.

Tô expondo a minha língua, mesinto mais à vontade. Porqueainda incorro num erro.

É mais fácil com quem realmente observa os D oze Passos, as idéias coadunam mais porque tem condição de entender profundamente.

Porque AA entende a língua da gente.

Sinto aproximação mais rápida entre eu e os companheiros do que fora, apesar disso não me impedir. A diferença é criada pelo outro lado, porque poucos entendem esse meu lado.

Pela troca deexperiências e o apren dizado. Porque são pessoas mais compreensivas, a maioria, que a gente confia.

Pela amizade, muitas vezes a gente nunca se conheceu mas parece amigo há 20 anos! $O$ utro povo não fala a minha língua.

Pelo carinho que recebo dos companheiros e companheiras. Viajo bastante para me comunicar com todos os estados. Porque não posso chegar e me comunicar com quem está bebendo.

Porque sou bem servido, convivo mais, quando tô em situação difícil procuro os companheiros. O s outros vão dizer: "toma uma que passa..."

Pela simplicidade de falar, porque tivemos a mesma doença, ele sente a mesma coisa, do jeito que eu falar ele vai aceitar numa boa.

Porque os AAs sabem entender a gente melhor do que as outras pessoas.

\section{No U ruguai}

H á maior profundidade e sinceridade, e mais assuntos.

N os conhecemos num dia ejá nesse dia écomo senos conhecêssemos toda a vida. 
A paz. Com os companheiros me entendo melhor do que com a gente de fora. $M$ ais alegria e mais respeito com os não-al coólicos.

Posso expressar-me melhor e ser melhor compreendido por um AA do que por outras pessoas, sem dissimulações.

Pessoas não-al coólicas não acreditam que falamos a verdade, na vida social não nos abrimos com facilidade.

Aqui temos um idioma muito nosso, lá fora os relacionamentos e a maneira de pensar são diferentes.

Com AAs tenho assunto, com os demais falo só o necessário, não tenho assunto, não há interesse.

Sinto maior proximidade, "já nos conhecemos toda a vida".

0 amor a um alcoólico, temos sentimentos distintos.

$M$ ais sinceridade e confiança (fora há desconfiança).

Sou mais sincera, mais ouvida e confio mais nos AAs.

0 que temos em comum chama muito mais a minha atenção: a doença, assuntos profissionais, estresse etc.

U ma expressão foi muito usada: fala-se "dentro" da associação uma mesma língua ou linguagem, que não é empregada "fora". A natureza dessa "linguagem do coração" (tal como osAAs a chamam) édada por aquela comunicação intersubjetiva de quejá falamos, que permite verdadeira comunhão dos sujeitos. Resta acrescentar que a prática da narrativa das histórias pessoais cria nos grupos um jargão específico, um conjunto de gírias e expressões com significados só acessíveis para seus membros, além de um repertório comum de histórias, metáforas, piadas que cotidianamente são usadas como referência e constantementemodificadas, atualizadase ressignificadas (tal como acontece em outras instituições).

Além disso, o verdadeiro treinamento informal dado pela participação a longo prazo nos grupos permite desenvolver aptidões para melhor compreender e intervir/ transformar o mundo ${ }^{17}$ - o que pode representar, paradoxal mente, um fator dificultador da comunicação fora de AA, caso tais condições sejam muito diferentes da média do repertório social contemporâneo - em particular no contexto latinoamericano: "os de fora não entendem" porque "a maneira de pensar é diferente".

${ }^{17}$ Algumas dessas aptidões são explicitadas e analisadas na tese da autora (Ganev 2002). 
D e todo modo, tais diferenças não resultam numa desqualificação ou culpabilização a priori dos não-al coólicos. Pelo contrário, as falas limitam-se a descrevêlase chegam a (auto)criticar a delimitação dentro/fora: "ainda incorro num erro" e "apesar disso não me impedir" (não impedir sua comunicação com não-alcoólicos). São indícios de que tal delimitação não évista como vantagem em si, mas como necessidade, de preferência passageira.

No mais, as falas apontam uma lacuna nas possi bilidades de uma comunicação profunda e aberta com os "de fora", dada pela diferença de vivências e pelo desconhecimento ainda generalizado da dimensão patológica e endêmica do alcoolismo, associado a um traço cultural pelo qual o beber e até a figura do bêbado são socialmente valorizados ${ }^{18}$.

\section{Contrapontos culturais}

U ma segunda característica a comentar referese a certos contrapontos que, no contexto latinoamericano ena perspectiva deuma integração regional vol tada à emancipação humana, a proposta de AA oferece à consciência de seus membros, nas marcas que inevitavelmente preservou enquanto proposta de um movimento nascido nos anos 30 do século passado, nos Estados U nidos, entre homens brancos, de classe média e majoritariamente protestantes.

\footnotetext{
${ }^{18}$ Beber socialmente não representa, realmente, nenhum problema para 85 a 90\% da população de qualquer lugar, segundo a estimativa da OMS. Todavia, para os 10 a 15\% restanteséuma prática potencialmenteletal. Nesse contexto é que AA passa a ser "segunda família" ou porto seguro ("os outros vão dizer: 'toma uma que passa"). A convivência social pode ser percebida como risco inevitável - um risco calculado enormalmenteassimilado pelos que já se sentem mais fortalecidos em sua recuperação, como talvez seja o caso dos membros que se comunicam igualmente bem entresi ecom pessoasnão-alcoólicas (48\%dos brasileirose 19\%dos uruguaios que responderam 0 questionário). Mas um risco ainda temido pelos mais novatos, eque os leva, eventualmente, a se tomarem temporariamente seletivos e criteriosos na (re) construção de seus laços sociais: é comum ouvir relatos de membros que evitam participar de eventos sabidamente etílicos, como uma renúncia/escolha consciente e determinada pela percepção de um limite pessoal. Outros passam por uma sutil transformação em relação a valores e gostos, não sentindo mais prazer em ambientes excessivamente regados a álcool (sóbrios, passam a observar a qualidade das relações que aí se estabelecem; comumente notam, ainda que não o queiram, a performance de quem está mais alcoolizado, e o efeito espelho - "esse aí sou eu ontem" - não é lá muito agradável) e passam a cultivar uma genuína preferência por outras atividades e formas de convivência consideradas mais prazeirosas, saudáveis e, por que não, também mais seguras: receber amigos em casa, praticar esportes, viajar ou simplesmente conversar. Essa diversidadeinterna de visões e estratégias permite enten der porque, embora a associação mantenha uma postura de neutralidade frente às políticas públicas, publicidade e hábitos socialmente instituídos relativos ao beber, encontremos membros que se declaram anti-alcoólicos (especialmente entre os mais novos).
} 
Em outras palavras, a pesquisa focalizou a reapropriação que uma parcela dos bêbados brasileiros e uruguaios fez e faz, desse movimento cultural nascido em outras terras e em meio a outros valores, crenças e práticas sociais, e importa dizer que tal reapropriação eventualmente redunda em auto-consciência cultural, em capacidade de olhar criticamente os próprios valores, saberes e práticas - políticos, ideológicos, religiosos, étnicos etantos outros, herdados detempos remotos. $M$ aisque isso, resulta eventualmente num processo de auto-lapidação cultural, feito de escolhas mais conscientes dentro de limites muitas vezes também conscientes, e que portanto podem ser deslocados em al guma medida.

Passarei a especular em torno dealguns aspectos, emuitas possibilidades de leitura se abrem ante uma tal especulação. 0 s limites da pesquisa levaram-me à escolha detrês obras clássicas de referência para a construção do comentário: AsVeiasAbertas da América Latina, Raízes do Brasil e 0 Povo Brasileiro.

Sérgio BuarquedeH olanda (2000) aponta heranças datradição ibérica quepermaneceram vivas efortes entre nós, brasileiros. Limito-mea citar o forte culto à personalidade, a fraca solidariedade, fraca organização social, e um forte dualismo mando/ obediência materializado historicamente em ditaduras e coronelismos. Além disso, o autor descreve uma ética de aventureiro que almeja fins "fáceis" ea qual quer custo, marcada pelo descompromisso e por atitudes predatórias para com o entorno. Finalmente, afirma que " $U \mathrm{~m}$ amor pronunciado pelas formas fixas e pelas leis genéricas, que circunscrevem a realidade complexa e difícil dentro do âmbito dos nossos desejos, édos aspectos mais constantes esignificativos do caráter brasileiro". Assim, "Tudo quanto dispense qualquer trabalho mental aturado e fatigante, as idéias claras, lúcidas, definitivas, que favorecem uma espécie de atonia da inteligência, parecem-nos constituir a verdadeira essência da sabedoria" (op.cit.: 158).

Direi que a cultura de AA parece sintonizar profundamente, tanto com nossa resistência à organização - já que se oferece como uma composição de sub e autoregulação - , quanto com o apego às formasfixas e genéricas, por apoiar-se em formulações imutáveis (Passos, Tradições e Conceitos). Por outro lado, provoca e confronta os ex-bêbadosbrasileiroscom outros traços mencionados por $\mathrm{H}$ olanda, por exemplo, ao valorizar 0 anonimato ("os princípios acima das personalidades"), o não-governo, a democracia, autonomia, uma ética de responsabilidade social, disciplina e trabaIho, forte solidariedade e (contraditoriamente) a busca de complexidade: auto-conhecimento, identidade $\&$ alteridade, minúcia, tolerância, auto-suficiência financeira $\&$ não-acumulação material, honestidade.

$\mathrm{N}$ as reuniões de grupo, aqui e ali ouve-se referências críticas a supostas marcas de identidadenacional ${ }^{19}$, indicando a emergência de uma consciência cultural que pode 
ir além do senso comum porque permite, a sujeitos equipados com elementos da cultura de $A A$, uma movimentação mais autônoma através da própria cultura, isto é, al gum grau de libertação da força condicionante que tais fatores exercem quando permanecem impercebidos, e que é fundamental na construção da tolerância e da democracia necessárias à vida social numa perspectiva de emancipação do homem.

D arcy Ribeiro (1995) recupera heranças ainda mais ancestrais e amplas, dos nossos índios e negros, e por isso propõe um olhar mais minucioso e mais otimista sobre o passado e as atualidades do nosso ser enquanto povo, que conflui para a mesma perspectiva emancipatória alimentada por tantas fontes, dentre as quais a micro-fonte de Alcoólicos Anônimos. $\mathrm{N}$ as páginas finais do livro que sintetiza as compreensões de toda sua vida, o antropólogo situa os brasileiros como um "povo em ser", que finalmente superou a ninguendade imposta nos primeiros séculos da colonização para tornar-se "mestiço na carne e no espírito, já que aqui a mestiçagem jamaisfoi crime ou pecado". Para Ribeiro, o desafio desse "povo novo, em fazimento" é "reinventar o humano, criando um novo gênero de gentes, diferentes de quantas haja" - ele fala dos brasileiros como uma civilização

mestiça e tropical, orgulhosa de si mesma. M ais alegre, porque mais sofrida. $M$ elhor, porque incorpora em si mais humanidades. $M$ ais generosa, porqueaberta à convivência com todas as raças e todas as culturas... (op.cit.: 447-9)

A pluralidade humana deAA (não só nos países aqui em foco) decerto comunga profundamente com tal característica macro-social dos brasileiros, uma potencializando a outra nas comunidades aonde funcionam grupos da associação.

Por outro lado, quando Ribeiro categoriza os uruguaios como "povo transplantado" (um bloco "que representa nas Américas tão-só a reprodução de humanidades e de paisagens européias", no qual o autor inclui ainda Argentina, EUA, Canadá, África do Sul branca e Austrália), "invadido por uma onda gringa que lançou 4 milhões de europeus sobre um mero milhão que havia devassado o país e feito a independência, soterrando a vel ha formação hispano-índia", não faz mais que atualizar, mais de vinte anos depois, os relatos de Eduardo $G$ al eano (1979) acerca do massacre dos charruas, da desastrosa campanha daquele país na Guerra do Paraguai, e da ditadura militar esmagando também lá as últimas resistências nacionalistas.

\footnotetext{
${ }^{19}$ Faço aqui algumas citações de memória: "não quero mais levar vantagem em tudo"; "chega de aplicar 171"; "hojefiz uma coisa boa que não preciso contar porque basta eu saber que fiz eme sentir bem com isso"; "somos servidores e não senadores".
} 
São imagensque, mesmo à distância eindiretamente, sintonizam com certas diferenças entre os AAs brasileiros e uruguaios aprendidas no presente estudo. Em suas respostas ao questionário, os primeiros afirmaram-se relativamente mais expansivos e afetivos mermo durante a ativa é́lica, enquanto os segundos permanecem comparativamente menos comunicativos, mais frios e agressivos mermo na atual fase de sua reauperação ${ }^{20}$. Para além de qualquer fator interno a Alcoólicos Anônimos, tal retraimento dos AAs uruguaios pode bem estar relacionado a sobrevivências do seu terrível embate macro-histórico. N esse caso, a cultura de AA estaria antes contribuindo para mitigar o peso dessa carga ancestral, ao oferecer, ainda quetardiamentee apenas para essa restrita comunidade, práticas deinclusão cultural e vivências de relações de alteridade fundadas no respeito e na tolerância ${ }^{21}$.

\section{Integração latinoamericana}

O olhar de G aleano sobre a América L atina permanece como denúncia sempiterna do aborto das potencialidades de uma integração soberana entreos povos do continente, em função dostrágicosmovimentos deisolamento aqui impostos após séculos de dominação econômica, política e ideológica: “...este conjunto de ilhas que é a América Latina, desgarrada por tantas fronteiras etantas incomunicações. Q ual integração podem realizar, entre si, países que nem sequer se integraram internamente?".

Pergunta ainda mais pertinenteneste século XXI, deglobal ização neoliberal mantendo os protecionismos de sempre e impondo vínculos que antes ampliam as distâncias entre povos muitas vezes vizinhos ${ }^{22}$. Todavia, o mesmo autor dirá que, "na história dos homens, cada ato de destruição encontra sua resposta - cedo ou tardenum ato de criação" (op.cit.: p. 307).

O ra, no plano das micro-iniciativascoletivasquehomens emulheres do continente empreendem no seu cotidiano, na perspectiva sempreviva da integração sonhada por

\footnotetext{
${ }^{20}$ Durantea ativa etílica, 44\% dos brasileirose $75 \%$ dos unuguaiosque responderam ao questionário, "ficavam mais agressivos quando alcoolizados"; 68\% dos brasileiros e 87\% dos unuguaios eram "mais frios, distantes, impessoais"; $32 \%$ dos brasileiros, mas apenas $12 \%$ dos uruguaios eram "afetivos por palavrase gestos". E, durante a recuperação, $4 \%$ dos brasileiros, mas 31\% dos unuguaios afirmaram-se "ainda pouco comunicativos"; $8 \%$ dos brasileiros, mas $37 \%$ dos uruguaios "ainda evitam o toque físico", a afetividade por gestos; confirmando esse último item, 92\% dos brasileiros, masapenas 62\%dosuruguaiosusam "normalmente" o toquefísico em seusrelacionamentose contatos. ${ }^{21}$ Oleitor que conheça mais extensa e profundamente os modos de ser do povo uruguaio poderá levantar outros aspectos nessa discussão.

${ }^{22}$ Vide o modo como a crise "argentina" comprometeu as bases do Mercosul ( desde sempre frágeis em função de políticas definidas fora do seu âmbito, por outros atores, no cenário mundial).
} 
Galeano e por tantos outros - soberana porque de povos e não de capitais ${ }^{23}$ - , podemos inferir, pelo quevimos até aqui, que a proposta, a cultura e as práticas de Alcoólicos Anônimos incorporam tanto a noção de relações internacionais como de integração na perspectiva dehumanização dos sentidos do homem. N ão a integração geral dos povos, mas a singela integração da pequena parcela de ex-bêbados de todo o mundo os quais escolheram tal vínculo de pertença. 0 mesmo acontece com a noção de integração regional - não especificamente, mas também, latinoamericana.

E é interessante acrescentar que, dentre os vários fóruns internacionais de $A A$, existe a RED ELA (Reunión de Las Americas), que a cada 2 anos reúne representantes de países dos três continentes, independentemente da existência e qualidade de outras relações internacionais entretais países, no passado eno presente (econômicas, políticas, ideológicas, religiosas).

N essas reuniões, a troca de experiências baseia-se em especial nas dificuldades de estruturação da entidade nos vários países: organização, finanças, relações internas e externas etc. E são definidas iniciativas de "apadrinhamento de países", isto é, determinado escritório nacional empreende ações para apoiar a organização da entidade em países próximos. Por exemplo (segundo alguns relatórios recentes sobre a RED ELA disponíveis aos membros brasileiros), AA da Colômbia (que dispõe de um Comitê de Apadrinhamento a O utros Países) tem auxiliado na organização da associação na Venezuela, Bolívia, Chile, Panamá ePeru, enquanto osmexicanostêm estreitado contatos em Cuba, provendo literatura e disponibilizando sua experiência, e os brasileiros não têm se dedicado a essetipo de serviço (no quenos fazem lembrar do corporati vismo que compõe aquilo que chamamos, com as restrições de praxe, de cultura nacional, além do conhecido isolacionismo que caracteriza historicamente as relações do Brasil com os demais países latinoamericanos) ${ }^{24}$.

\footnotetext{
${ }^{23}$ Afinal, pordefinição, mesmo a "integrabilidade" doscapitaisestá quasesempreassociada ao arbítrio, à força, à comupção, enfim, a tudo quanto se opõea uma integração humanizada e humanizante das coletividades humanas em questão.

${ }^{24}$ Existe também, desde 1969, a Reunião de Serviço Mundial (RSM), que reúne representantes dos países que já dispõem de escritórios nacionais organizados (29, em 2000); nos anos em que não acontece a RSM, ocorrem as reuniões regionais, queincluem também paísesaondeAAainda está em processo de estruturação: além da REDELA, existem a Reunião de Serviço Européia, desde 1981, e a Reunião de Serviço da Ásia e Oceania, desde 1995. Existem ainda as Conven ções Internacionaisde AA, qüinqüenais, reunindo dezenas de milhares de membros para confratemização, e um Fundo de Literatura que, desde 1990, edita em 15 idiomas os principais títulos da bibliografia oficial da entidadee os distribui em países queainda não organizaram suas editoras. Ainda, nas Conferências eConvençõesnacionaisécomum a presença de convidados de paísesvizinhos. Finalmente, a Internet também vem sendo usada como ferramenta de integração: além das home pages de escritórios nacionais e locais, funcionam "grupos virtuais" em váriosidiomas que reúnem membros de diversas nacionalidades.
} 
Importa ressaltar que essas práticas de integração regional impõem um esforço significativo aos sujeitos da pesquisa (não só no Brasil e no U ruguai), seja pela crônica escassez de recursos financeiros dos escritórios nacionais ${ }^{25}$, seja por distintas formas de resistência que a idéia de integração acende, nas várias nacionalidades dos ex-bêbados.

$\mathrm{M}$ as, mesmo dentro de tais limites, resta claro que tais práticas, bem como a proposta deAA como um todo, abarca uma dimensão de integração regional significativa na perspectiva do presente estudo, e que pode ser vista como desdobramento concreto da relação de coerência entresua cultura institucional eas formas regulatórias/ organizativas que construiu e manteve ao longo de sua existência.

\section{Referências Bibliográficas}

ALCOÓ LICOS AN Ô N IM OS. São Paulo, JU N AAB, 1996.

BAKTH IN , M. A cultura popular na Idade M édia e no Renascimento. São PauloDF, H ucitec, 1993.

CÂN DID O , A. Os parceiros do Rio Bonito. São Paulo, Editora 34 e Livraria Duas Cidades, 2001.

CARD O SO, C.F.S. América Précolombiana. São Paulo, Brasiliense, 1986.

GALEAN O, E. Asveias abertas da América Latina. São Paulo, Paz eTerra, 1979.

GAN EV, E. D ize me como andas e saberei quem és. 0 método de Alcoólicos Anônimos à luz da comunicação social no contexto latinoamericano: B rasil eU ruguai. Tese de D outorado. São Paulo, PRO LAM /U SP, mímeo, 2002.

H O LAN D A, S.B. Raízes do Brasil. São Paulo, Companhia das Letras, 2000.

JAM ES, W. As variedades da experiência religiosa. U m estudo sobre a natureza humana. São Paulo, Cultrix, 1995.

M AN UAL DE SERVIÇOS DE AA. São Paulo, 1995.

OSD OZE PASSOSE ASD OZE T RAD IÇÕES. AlcoólicosAnônimos, São Paulo, 1995.

RIBEIRO, D. 0 povo brasileiro. São Paulo, Companhia das Letras, 1995.

SANTOS, B.S. "O Estado e o Direito na Transição Pós-M oderna: Para um novo Senso Comum". In: H umanidades. São Paulo, vol.7, no 3, 1991, pp. 267-282.

\footnotetext{
${ }^{25}$ Do mesmo modo que os grupos em geral operam com orçamentos restritivos (suficientes apenas para aluguel, tanifas públicaseocafezinho), também osescritóniosnacionaisoperam em geral com orçamentosquenãoinduem, noplanejamento de suas despesas regulares, os servicgos de relações públicas, apadninhamento a outros países e integração regional.
} 
SEIBEL, S.D . eTO SCAN O J r., A. Dependência de D rogas. São Paulo/Rio deJaneiro/Belo H orizonte, Atheneu, 2000.

VAILLANT, G.E. A hisória natural do alcoolismo revistada. Porto Alegre, ART M ED , 1999. www.alcoolicosanonimos.org.br 
Eliane Ganev - Cadernos PRO LAM /U SP (ano 2 - vol. 2 - 2003), p. 45-77 